\title{
前立腺癌の組織異型度とリンパ節転移
}

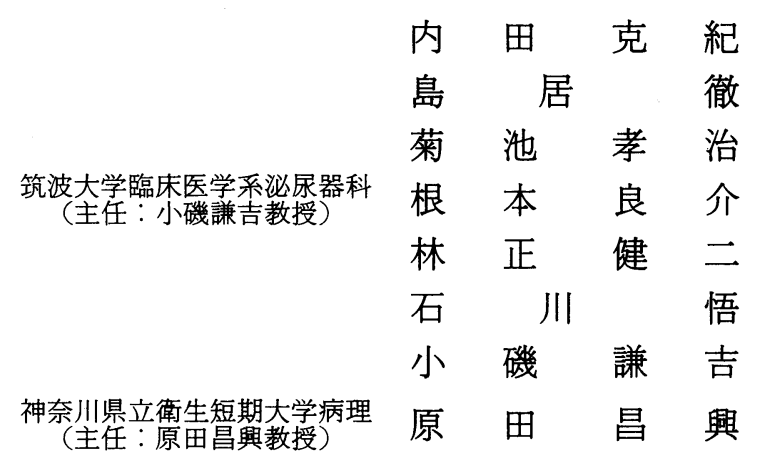

\section{THE RELATIONSHIP OF HISTOLOGICAL GRADE OF PROSTATIC CARCINOMA AND LOCAL TUMOR EXTENT TO PELVIC NODAL INVOLVEMENT}

\section{Katsunori Uchida, Toru Shimazui, Koji Kikuchi, Ryosuke Nemoto}

Kenji Rinsho, Satoru Ishikawa and Kenkichi Koiso

Department of Urology, Institute of Clinical Medicine, the University of Tsukuba, Ibaraki, Japan

(Director : Prof. Kenkichi Koiso)

Masaoki Harada

Department of Pathology, Kanagawa Prefectural College of Nurse and Medical Technology, Kanagawa, Japan

(Director: Prof. Masaoki Harada)

The relationship of tumor grade and local tumor extent to pelvic nodal involvement was assessed surgically in 17 patients who underwent pelvic lymphadenectomy for adenocarcinoma of the prostate.

The relationship of preliminary clinical stage and pelvic lymphnodal metastases was noted in neither of two patients (0\%) with stage A, 3 of $9(33 \%)$ with stage B, 5 of $6(83 \%)$ with stage C disease.

Of patients with a Mostofi's grade 1 , none $(0 / 4)$ had regional node metastases and all $(5 / 5)$ had metastasis in the case of grade 3.

Of patients with a Gleason score of 8 or above, all (5/5) had regional nodal metastases, regardless of preliminary clinical stage. Furthermore, no patient with Gleason score of 2, 3 or 4 had nodal metastatic disease $(0 / 3)$.

In two out of seven cases with pelvic nodal involvement, the grade of metastatic lesion was higher than that of primary lesion.

It is suggested that patients with high grade tumor are included in the group with widespread disease, and patients with low grade tumor are in the group with localized disease. But the ability to predict accurately nodal metastatic disease in patients with moderate grade tumor was variable and argues strongly against staging node dissection in this selected population.

要旨：骨盤内リンパ節郭清術を施行した前立腺癌症例17例を対象に，原発巣とリンパ節転移との関係を 病理組織学的に検討した。

前立腺癌の術前 stage とリンパ節転移との関係では, stage A で0/2例( $0 \%$ ), stage B で3/9例(33\%), stage Cで5/6例（83\%）に転移が認められた。

前立腺癌原発巣の Mostofi 分類とリンパ節転移との関係では, Grade 1 で0/4例 ( $0 \%$ \%), Grade 2 で 3/8例 (38\%), Grade 3 で5/5例 (100\%) に転移が認められた。 
前立腺癌原発巣の Gleason score 8-10 の症例は全例（5/5例）にリンパ節転移を認めたのに対し， Gleason score 2-4 の症例では一例もリンパ節転移を認めなかった $(0 / 3$ 例).

リンパ節転移が認められた 7 症例中 2 症例に执いて原発巣の組織学的異型度よりも転移巣のそれの方 が高かった。

原発巣の異型度が 1 （Gleason score 2-4）または3（Gleason score 8-10）のものについては組織 学的所見からリンパ節転移の有無を類推することは可能であるが，異型度 2（Gleason score 5-7）の 症例については他の要因を含めた検討が必要と思われた。

\section{緒言}

前立腺癌の治療方針は局在癌であるか進行癌である かによって大きく異なる ${ }^{1) 31}$. 進行癌に対してはェス トロゲン療法を主体としており，化学療法も検討され ている。一方, 遠隔転移のない局在癌に対しては根治 手術を主として放射線療法などが組み合わされてい る. 最近, 骨転移の有無だけでなくリンパ節転移の有 無についても予後との相関性が報告され4)，治療方針 の決定に重要な因子となっている，特に，組織学的な リンパ節転移の有無を検索するための staging operationの重要性が強調され，遠隔転移のない局在癌にも リンパ節転移が数多くみつかると報告されてい $る^{5) \sim 7)}$.

一方, 前立腺癌は組織学的悪性度と臨床病期および 予後との関係が密接で, 原発巣の正確な病理組織学的 診断が治療方針の決定に役立つことが少なくな $\left({ }^{8) 9}\right.$. 最近では, 前立腺癌の原発巣の組織型とリンパ 節転移との関係に興味がもたれ，両者の間が極めて良 く相関するとの報告もある5)10).

今回, 我々は骨盤内リンパ節郭清術による staging を施行した症例を対象に, 前立腺癌の原発巣とリンパ 節転移の有無について臨床病理学的検討を行ったので 報告する。

\section{対象および方法}

1980年 8 月より 1985 年 8 月までの 5 年間に筑波大学 附属病院に扣いて骨盤内リンパ節郭清術による stagingを抗こなった 17 名を対象とした。年齢は50歳から 78歳で平均 66.9 歳であった。

全例とも術前に骨シンチスキャン, 超音波検査, CTscan, リンパ管造影, 血液生化学的検査で明らかな リンパ節転移および他藏器への遠隔転移がないことを 確認した。な捺発巣の浸潤度は前立腺癌取り扱い 規約 ${ }^{11)}$ に従い直腸診, 経直腸的超音波検查技よび前立 腺部のCTscanにより総合判定し臨床病期を決定し た. stage A 癌は前立腺摘出標本の総てを step-section 法により検索して発見された症例で, $\mathrm{A}_{1}$ 癌はリンパ節
郭清術の対象から除外した ${ }^{12) ~ 14) . ~}$

我々が行っている前立腺癌に対するリンパ節郭清術 の詳細については既に林正らが報告した ${ }^{15)}$. 摘出した リンパ節は傍大動脈，総腸骨動脈，外腸骨動脈，内腸 骨動脈および閉鎖神経周囲に分離しホルマリン固定の 後病理組織学的に検討した。

原発巣の組織学的検索には初回診断時の針生検標本 または摘出標本（stage Aの場合）を用いた。組織学 的分類は Gleason 分類 ${ }^{16)}$ 扔よび Mostofi の分類 ${ }^{177}$ に 従い，リンパ節転移の情報を白紙にして行った（K. U. \& M.H). Gleason 分類による score は primary pattern $(1 \sim 5)$ と secondary pattern $(1 \sim 5)$ の 和（2１0）で表した。なお，両分類法の詳細につい ては既に報告したと抢りである ${ }^{8) 918)}$.

\section{結 果}

staging operationにより得たリンパ節の病理組織 学的診断で17症例中 8 症例 (47\%) に転移を認めた。

臨床病期とリンパ節転移との関係では, stage $\mathrm{A}_{2}$ ( 2 例), stage $\mathrm{B}_{1}$ ( 1 例)には転移を認めなかったが, stage $\mathrm{B}_{2}$ には 8 例中 3 例 (37.5\%), stage $\mathrm{C}$ では 6 例中 5 例 （83.3\%）に転移を認めた（図 1).

図 1 臨床病期とリンパ節転移の有無

\begin{tabular}{c|c|c|c|c}
\hline Stage & $\mathrm{A}_{2}$ & $\mathrm{~B}_{1}$ & $\mathrm{~B}_{2}$ & $\mathrm{C}$ \\
\hline 転移- & 0 & 0 & 890 & $\bigcirc$ \\
\hline 転移 + & & & $\bigcirc 00$ & 800 \\
\hline
\end{tabular}

図 2 組織異型度 (Mostofi の分類) とリンパ節 転移の有無

\begin{tabular}{c|c|c|c}
\hline $\begin{array}{c}\text { Grade } \\
\text { (primary) }\end{array}$ & 1 & 2 & 3 \\
\hline 転移 - & 800 & 890 & \\
\hline 転移+ & & 000 & 880 \\
\hline
\end{tabular}


前立腺癌原発巣の組織学所見とリンパ節転移との関 係を検討したところ Mostofi の分類では Grade 1 で 0/4例, Grade 2 で $3 / 8$ 例, Grade 3 で5/5例に転移を認 めた (図 2). Gleason 分類では score 2-4 で0/3例 ( $0 \%)$, score $5-7$ で3/9例 (33.3\%), score 8-10 で 5/5例（100\%）に転移を認めた（図 3 ）.

stage B の 9 例において原発巣の組織像とリンパ節 転移との関係を検討したところ, Grade 1 で0/3例, Grade 2 で2/5例, Grade 3 で1/1例に転移が認められ た（図 4 ）.

リンパ節転移を認めた 7 症例において前立腺癌原発 巣とリンパ節転移巣の組織学的比較を Gleason 分類 を用いて行った。その結果， 2 症例で転移巣の異型度 が原発巣の異型度より高くなっていたが他の 5 例では 全く同一であった（図 5 ).

\section{考案}

臨床病期とリンパ節転移の有無に関する諸家の報告 を表 1 にまとめた. stage $A_{1}$ でリンパ節転移を認めた

図 3 組織異型度（Gleasonの分類）とリンパ節 転移の有無

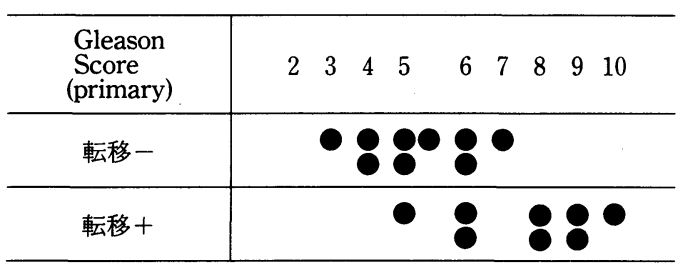

図 4 臨床病期 B における組織異型度 (Mostofi 分類）とリンパ節転移の有無

\begin{tabular}{c|c|c|c}
\hline $\begin{array}{c}\text { Grade } \\
\text { (primary) }\end{array}$ & 1 & 2 & 3 \\
\hline 転移- & 000 & 000 & \\
\hline 転移+ & & 0 & 0 \\
\hline
\end{tabular}

報告はなく, stage $\mathrm{A}_{2}$ で0〜20\%, stage B で10〜 50\%， stage Cで30 70\%にリンパ節転移が発見されてい

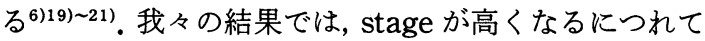
リンパ節転移をきたす率は高くなり欧米の報告と一致 した。ただし, stage $A_{2}$, stage $B_{1}$ でリンパ節転移を 認めた症例はなく，陽性例は総て $\mathrm{B}_{2}$ 以上であった。 た, stage C は 1 例を除いて総て転移を認め, 欧米の報 告に比べ高率であった。

原発巣の組織学的悪性度とリンパ節転移の有無につ いては多くの報告がある。組織分類にあたっては Broders らの唱えた gradingに基づくものと年22),

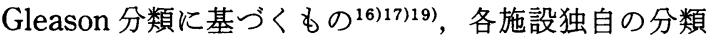
を用いたものの 3 つに分けることができる677).

表 2 には組織像を 3 段階に grading したときの報

図 5 前立腺原発巣とリンパ節転移巣の組織異型度 (Gleason 分類) の比較

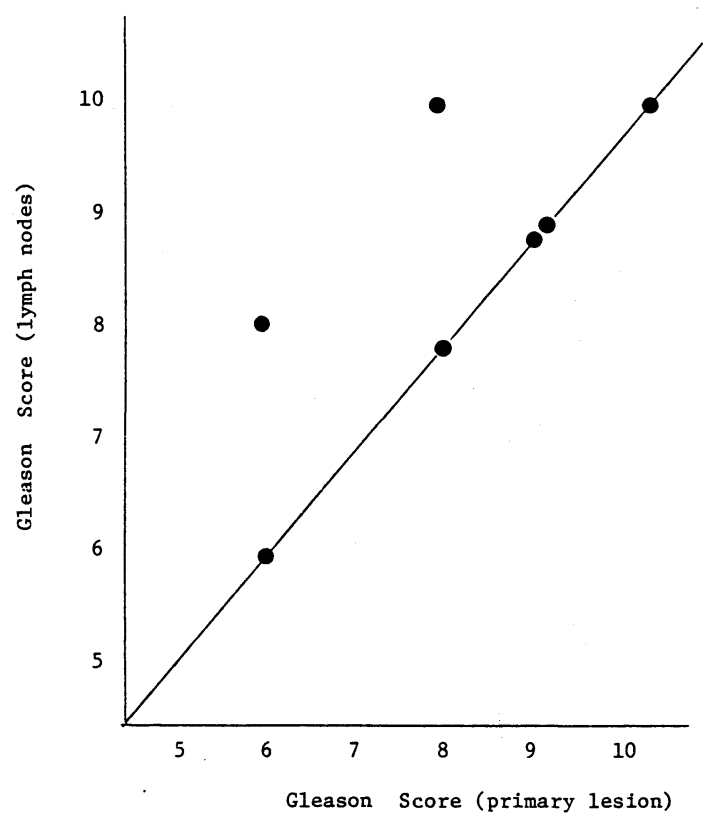

表 1 臨床病期とリンパ節転移の頻度に関する報告例

\begin{tabular}{l|c|c|c|c|c}
\hline Stage & $\begin{array}{c}\mathrm{A}_{1} \\
\mathrm{n}(\%)\end{array}$ & $\begin{array}{c}\mathrm{A}_{2} \\
\mathrm{n}(\%)\end{array}$ & $\begin{array}{c}\mathrm{B}_{1} \\
\mathrm{n}(\%)\end{array}$ & $\begin{array}{c}\mathrm{B}_{2} \\
\mathrm{n}(\%)\end{array}$ & $\begin{array}{c}\mathrm{C} \\
\mathrm{n}(\%)\end{array}$ \\
\hline Mclaughlin $^{6)}$ & & & $4 / 19(21)$ & $5 / 17(30)$ & $12 / 24(50)$ \\
Zinke et al. $^{19)}$ & & $0 / 9(0)$ & $1 / 183(0.5)$ & $13 / 24(10)$ & $54 / 148(35)$ \\
Lieskovsky et al. $^{20)}$ & $0 / 2(0)$ & $1 / 8(0)$ & $3 / 16(19)$ & $12 / 39(31)$ & $11 / 17(65)$ \\
Brendler et al. $^{21)}$ & $0 / 1(0)$ & $3 / 22(14)$ & $11 / 58(19)$ & $14 / 27(52)$ & $10 / 17(59)$ \\
Present study & & $0 / 2(0)$ & $0 / 1(0)$ & $3 / 8(38)$ & $5 / 6(83)$ \\
\hline
\end{tabular}


表 2 組織異型度 ( 3 段階分類) とリンパ節転移の 頻度に関する報告例

\begin{tabular}{l|c|c|c}
\hline Author & $\begin{array}{c}\text { Grade 1 } \\
\mathrm{n}(\%)\end{array}$ & $\begin{array}{c}\text { Grade 2 } \\
\mathrm{n}(\%)\end{array}$ & $\begin{array}{c}\text { Grade 3 } \\
\mathrm{n}(\%)\end{array}$ \\
\hline Barzell et al. ${ }^{23)}$ & $3 / 19(16)$ & $18 / 46(39)$ & $9 / 15(60)$ \\
Catalona and Stein $^{7)}$ & $3 / 38(21)$ & $10 / 34(29)$ & $9 / 16(56)$ \\
Prout et al. ${ }^{4)}$ & $0 / 16(0)$ & $18 / 51(35)$ & $14 / 25(56)$ \\
Smith et al. ${ }^{24)}$ & $12 / 125(10)$ & $65 / 275(24)$ & $28 / 52(54)$ \\
Present study & $0 / 4 \quad(0)$ & $3 / 8 \quad(38)$ & $5 / 5(100)$ \\
\hline
\end{tabular}

表 3 Gleason 分類とリンパ節転移の頻度に関する 報告例

\begin{tabular}{l|c|c|c}
\hline Gleason score & $\begin{array}{c}2-4 \\
\mathrm{n}(\%)\end{array}$ & $\begin{array}{c}5-7 \\
\mathrm{n}(\%)\end{array}$ & \multicolumn{1}{c}{$\begin{array}{c}8-10 \\
\mathrm{n}(\%)\end{array}$} \\
\hline Kramer et al. $^{10)}$ & $0 / 31(0)$ & $26 / 84(31)$ & $27 / 29(93)$ \\
Sagalowski et al. $^{25)}$ & $0 / 14(23)$ & $15 / 61(25)$ & $7 / 15(50)$ \\
Ollson et al. ${ }^{26)}$ & $9 / 39(23)$ & $16 / 75(21)$ & $14 / 23(61)$ \\
Zinke et al. ${ }^{19)}$ & $4 / 67(6)$ & $58 / 385(15)$ & $6 / 17(35)$ \\
Present study & $0 / 3(0)$ & $3 / 9 \quad(33)$ & $5 / 5(100)$ \\
\hline
\end{tabular}

告例をなとめた. Grade 1 では殆ど転移が認められな いのに対し，Grade 3 では $50 \%$ 以上に転移が認められ

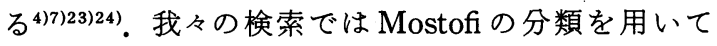
Grading を行った結果, Grade Iではリンパ節に転移 していた症例は無く, Grade 3 では全例が転移してお り Grade とリンパ節転移の有無が極めて良く相関し た.

一方, 組織構築の評価に重点を掞いた Gleason 分

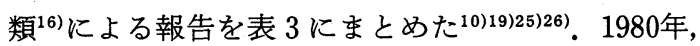

Paulson らが Gleason score 2-5の14\%，9-10の $100 \%$ にンパ節転移を認めたと報告し, 同年 Kramer らは Gleason score 2-4の 0\%，8一10 の93\%にリン パ節転移を認めたと報告した。この結果, 原発巣の Gleason 分類による判定がリンパ節転移の有無を判定 する指標となり得るとし, Gleason 分類で低異型度, 高 異型度と判定されたものには staging operationは不 要との見解を述べた5)10). その後, 原発巣の組織像とリ ンパ節転移との関係について多くの追試が行われ，

Olsson らは Gleason score 2-4 の20\%以上にリンパ 節転移を認め，8一-10の $40 \%$ には転移を認めなかった と報告した ${ }^{26)}$. Zinke らも, Gleason score 2-4の $6 \%$ にのみリンパ節転移を認めたが， 8-10でも35\%しか 転移を認めなかったと報告している19). いずれる Gleason 分類をリンパ節転移の有無を判定する指標と することに批判的で，Zinke らは彼ら独自の診断法を
推奨している ${ }^{19)}$. 今回, 我々は僅か 17 症例に対してでは あるがこの追試を行い, Gleason score 2-4の 3 例に は全く転移を認めず，8-10の 5 例には全例にリンパ 節転移を認め, Kramer らの報告とよく似た傾向を示 した。

Mostofi 分類と Gleason 分類による結果を合わせる と, 原発巣の組織像が grade 1 (Gleason score 2-4) もしくは grade 3 (Gleason score 8-10) の症例につ いてはリンパ節転移の有無を予想できるような成績で あった。但し, Grade 2 (Gleason score 5-7) の症例 では組織学的検索のみでリンパ節転移の有無を類推す ることは困難と思われた. Grade 2 に関しては, nuclear roundness factorによる再分類の方法 ${ }^{27)}$ や電 顕写真の導入 ${ }^{28)}$ などが有効との報告もあり，新しい画 像診断方法の開発を含め今後の検討が必要と思われ る.

Prout らは前立腺癌の全摘標本と転移巣の組織を比 べて，原発巣の分化度が中等度であった 18 例のうち 4 例で転移先の分化度が原発巣よりも低くなっており， 原発巣が低分化型であった14例では転移先でも同様で あったと報告している4). 我々の結果も，症例こそ少な いが彼らの報告とよく似た傾向を示した.ただし，我々 の症例はいずれもリンパ節郭清術で転移が証明された ため，全摘術を施行して扣らず原発巣の診断は針生検 のみで行った. そのため，針生検による採取部以外の 組織中に高異型度の組織が在存していた可能性も否定 できない，針生検による組織学的判定が全摘標本によ るものに比べ under grading になり易いとする報告も

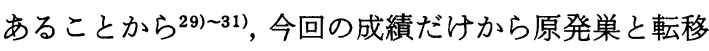
巣の組織像の違いを論ずることは出来ない.しかし， この問題は癌病巣の heterogenesity と転移といら観 点で非常に興味があり, 今後さらに症例を重ねて検討 したい。

\section{結 語}

術前検査で遠隔転移のない前立腺癌症例17例に対し リンパ節郭清術による staging を施行し, 原発巣の組 織像とリンパ節転移の関係を検討した。その結果, 前 立腺癌のリンパ節転移の有無は原発巣の臨床病期, 組 織悪性度とよく相関している成績が得られた。

本論文の要旨は第 23 回癌治療学会総会 (昭和60年10月) に て発表した.

\section{文献}

1) Thompson, G.J.: Transurethral resection of malignant lesions of the prostate gland. J.A.M. 
A., 120, 1105-1109, , 1942.

2) Emmett, J.L., Greene, L.F. and Papantoniou, A.: Endocrine therapy in carcinoma of the prostate gland: 10-year survival studies. J. Urol., 83, 471-484, 1960.

3) Mellinger, G.T., Gleason, D. and Bailar, J. III. : The histology and prognosis of prostatic cancer. J. Urol., 97, 331-337, 1967.

4) Prout, G.P., Heaney, J.A.M Griffin, P.P., Daly, J. J. and Sipley, W.U.: Nodal involvement as prognostic indicator in patients with prostatic carcinoma. J. Urol., 124, 226-231, 1980.

5) Paulson, D.F.: The prognostic role of lymphadenectomy in adenocarcinoma of the prostate. Urol. Clin. North. Am., 7, 615-622, 1980.

6) Mclaughlin, A.P., Saltzstein, S.L., Mccullough, D.L. and Hittes, R.F.: Prostatic carcinoma: Incidence and location of unsuspected lymphatic metastases. J. Urol., 115, 89-94, 1976.

7) Catalona, W.J. and Stein, A.J.: Staging erriors in clinically localized prostatic cancer. J. Urol., 127, 452-456, 1982.

8) Harada, M., Mostofi, F.K., Corle, D.K., Byar, D. P. and Trump, G.F.: Preliminary studies of histologic prognosis in cancer of the prostate. Cancer Treat. Rep., 61, 223-225, 1977.

9）原田昌興：前立腺癌の生検組織診断. 臨床病理, 26, 877-884, 1978.

10) Kramer, S.A., Sparh, J., Brendler, C.B., Glenn, J. F. and Paulson, D.F.: Experience with Gleason's histopathologic grading in prostatic cancer. J. Urol., 124, 223-225, 1980.

11) 日本泌尿器科学会, 日本病理学会: 泌尿器科, 病 理, 前立腺癌取り扱い規約, 第1版, 金原出版, 東 京, 1985 .

12) Uchida, K., Shimazui, T., Nemoto, R., Rinsho, K., Koiso, K. and Harada, M. : Clinicopathological study of prostatic cancer: Study of unsuspected cancer on the suprapubic prostatectomy specimens,. (in press).

13) Nemoto, R., Harada, M., ;Uchida, K. and Koiso, $\mathrm{K}$.: Incidental carcinoma of the prostate: Histopathology and natural history. Jpn. J. Clin. Oncol., 15, 619-623, 1985.

14) Nemoto, R., Harada, M., Uchida, K. and Koiso, $\mathrm{K}$. : Incidental carcinoma in Japan: tumor size and histological characteristics. Appl. Pathol. 3, 215-220, 1985.

15）林正健二, 石川 悟, 根本良介, 小磯謙吉, 武島 化, 内田克紀：前立腺癌に怙ける骨盤内リンパ節 郭清術の検討. 泌尿紀要, 31, 1583-1587, 1985.
16) Gleason, D.F., Mellinger, G.T. and the Veterans Administration Cooperative Urological Research Group: Prediction of prognosis for prostatic adenocarcinoma by combination histological grading and clinical staging. J. Urol., 111, 58-64, 1974.

17) Mostofi, F.K.: Grading of prostatic carcinoma. Cancer Chemother Rep., 59, 111-117, 1975.

18）内田克紀, 根本良介, 石川 悟, 小磯謙吉, 原田昌 興：前立腺癌の臨床病理学的研究. Gleason 分類 に上る本邦例と米国例との組織学的比較。日泌尿 会誌, 78, 24-29, 1987.

19) Zincke, H., Farrow, G.M., Myers, R.P., Benson, M.R. Jr., Furlow, W.L. and Utz, D.C.: Relationship between grade and stage of adenocarcinoma of the prostate and regional pelvic lymphnode metastases. J. Urol., 128, 498-501, 1982.

20) Lieskovsky, G., Skinner, D.G. and Weisenburger, T.: Pelvic lymphadenectomy in the management of carcinoma of the prostate. J. Urol., 124, 635-638, 1980.

21) Brendler, C.N., Cleeve, L.K., Anderson, E.E. and Paulson, D.F.: Staging pelvic lymphoadenectomy for carcinoma of the prostate: Risk versus benefit. J. Urol., 124, 849-850, 1980.

22) Broders, A.C.: Carcinoma : Garding and practical application. Arch. Pathol., 2, 376-381, 1926.

23) Barzell, W., Bean, M.A., Hilaris, B.S. and Whitmore, W.F. Jr.: Prostatic adenocarcinoma : Relationship of grade and local extent to the pattern of metastases. J. Urol., 118, 278-282, 1977.

24) Smith, J.A. Jr., Seaman, J.P., Gleidman, J.B. and Middleton, R.G.: Pelvic lymph node metastatic cancer: Influence of tumor grade and stage in 452 consecutive patients. J. Urol., 130, 290-292, 1983.

25) Sagalowsky, A., Milam, H., Reveley, L.R. and Silva, F.: Prediction of lymphatic metastasess by Gleason histologic grading in prostatic cancer. J. Urol., 128, 951-952, 1982.

26) Olsson, C.A.: Staging lymphadenectomy should be an antecedent to treatment in localized prostatic carcimoma. Urology, 25 supplement to Feb : 4-6, 1985.

27) Epstein, J.I., Berry, S.J. and Eggleston, J.C.: Nuclear roundness factor: A predictor of progression in untreated stage $A_{2}$ prostate cancer. Cancer, 54, 1666-1671, 1984. 
28) Tannenbaum, M., Tannenbaum, S., Desanctis, P.N. and Olsson, C.A. : Prognostic significance of nucleolar surface area in prostate cancer. Urology, 19, 546-551, 1982.

29) Muller, H.A., Ackermann, R., Heckl, W. and Frohmuller, H.G.W.: Th value of perineal punch biopsy in estimating the histological grade of carcinoma of the prostate. Read at annual meeting of the American Urological Association, San Franciesco, California, May 18-22, 1980.

30) Lange, P.H. and Narayan, P.: The need and tolerance of adjuvant radiation therapy (RT) after radical prostatectomy (RP) for carcinioma of the prostate (CAP). Read at annual meeting of the North Central Section, American Urological Association, Hamilton, Bermuda, November, 9-16, 1980.

31) Catalona, W., Stein, A.J. and Faira, W.R.: Grading errors in prostatic needle biopsies: Relation to the accuracy of tumor grade in predicting pelvic lymph node metastases. J. Urol., 127, 919-922, 1982.

（1986年 3 月 31 日受付，特別掲載） 